\title{
Quality characteristics of Sikhye prepared by different ratio of Seomaeyaksuk (Artemisia argyi H) extract
}

\author{
Jeong Yeon Shin, Yeon U Woo, Yu Lim Jo, Weon Taek Seo, Jine Shang Choi* \\ Department of Food Science, Gyeongnam National University of Science and Technology, Jinju 52725, Korea
}

\section{섬애약쑥 추출물의 첨가 비율에 따른 식혜의 품질특성}

\author{
신정연 · 우연우·조유림 · 서원택·최진상* \\ 경남과학기술대학교
}

\begin{abstract}
This study was conducted to increase the functionality of Korean traditional beverage, Sikhye. The Sikhye were prepared by supplementation up to $\mathbf{2 0 \%}$ of Seomaeyaksuk extract (SE) and saccharification for five hours (h). During the saccharification, turbidity of SE-added Sikhye (SES) was the highest at two hours of saccharification and then lowered gradually. $L$ vlaue of SES did not show significant difference feduring saccharification, and both a and b value of Sikhye were increased as saccharification time passed and $\mathrm{SE}$ addition ratio was increased. The pH before saccharification was not significantly different by $\mathrm{SE}$ addition ratio but it was increased to 5.68-5.73 at $5 \mathrm{~h}$ saccharification. Soluble solid, total sugar and reducing sugar contents were enhanced as saccharification time and SE addition ratio were increased. The total phenolic compounds contents and DPPH radical scavenging activity showed a similar trend by saccharification time and SE addition. In sensory test, the evaluations of $\mathbf{5 \%} \mathrm{SES}$ and control were not significant different, but $20 \%$ SES group showed significant lower evaluation than other groups because strong color and mugwort flavor. From all of these results, physicochemical characteristics and antioxidant activity of SES was improved by SE addition but sensory characteristics was lower. Acceptable addition ratio of SE in Sikhye is determined to be within $15 \%$.
\end{abstract}

Key words : Seomaeyaksuk, Sikhye, saccharification, physicochemical chracteristics

\section{서 론}

국화과의 다년생 초본인 쑥(Artemisia sp.)은 아시아뿐만 아니라 유럽, 아프리카 등에도 자생하는데, 번식력과 환경 적응력이 강하고 다른 식물과의 경쟁에서 우세하며 오랜 야생의 역사로 인하여 변이종이 많아 전 세계적으로 약 400 여 종이 분포되어 있고, 우리나라에만도 300 여 종이 자 생하는데 대표적으로 인진쑥, 약쑥, 참쑥, 산쑥 등이 있다 $(1,2)$. 쑥은 우리나라 어느 지역에서나 쉽게 얻을 수 있어

*Corresponding author. E-mail : jschoi@gntech.ac.kr Phone : 82-10-6581-3275, Fax : 82-55-751-3279

Received 30 September 2016; Revised 23 February 2017; Accepted 4 April 2017.

Copyright (c) The Korean Society of Food Preservation. All rights reserved.
우리에게 친숙한 식물류로 과거에서부터 식용뿐만 아니라 약용으로도 널리 이용되어 왔는데, 이는 쑥이 품종에 관계 없이 어느 것이나 특징적인 생리활성 기능을 가지고 있기 때문이다(3). 쑥의 일반적인 약리적 효능으로는 항산화, 항 균, 항염증, 항암, 혈압강하, 항궤양, 항알레르기 작용이 있 으며, 지혈작용, 피부미용과 피부질환 억제작용 등이 알려 져 있다(4)

전통음식에서 쑥을 사용한 예로는 술, 쑥밥, 쑥국수, 쑥경 단, 쑥차, 떡, 국, 무침, 나물 등이 있으며, 복통, 설사, 위장병, 부인병, 저혈압, 간기능 항진, 동맥경화 등의 질병에 적용하 기도 하였다(2). 최근에는 전통 식품에 쑥을 적용하여 품질 개선 또는 기능성을 활용하고자 하는 연구들이 진행되고 있다. 쑥을 첨가한 매작과의 저장 중 항산화 활성에 관련한 연구(5), 쑥 분말을 첨가한 양갱(6), 쑥을 첨가한 팽화 방법 을 달리한 유과(7) 및 개똥쑥 분말을 첨가한 절편(8)의 품질 
특성과 관련한 보고들이 있으나 아직까지 음청류에 적용한 연구는 거의 이루어지고 있지 않다.

정확한 기원은 알려져 있지 않으나 오래 전부터 우리나 라 고유의 음청류로 자리잡아온 식혜는 발아한 보리싹을 말린 엿기름 추출액 속에 있던 amylase가 멥쌀이나 찹쌀로 지은 고두밥을 당화시킴으로써 maltose와 glucose 등으로 분해되어 감미와 특유의 풍미가 생성되므로 단술 또는 감주 라고 불린다(9).

전통음료에 대한 소비자 선호도 조사 결과 식혜는 전통 음료 중 남녀 모두에게서 가장 인지도가 높은데, 전통음료 를 소비하는 주요 목적이 건강에 도움을 줄 것으로 기대되 기 때문이라고 보고되어 있다(10). 이러한 관점에서 볼 때 식혜는 인지도는 가장 높으나 제조과정에서 생성되는 당분 과 기호성의 증진을 위해서 첨가되는 당류로 인하여 영양학 적 가치는 제한적이므로 여러 가지 천연 기능성 소재를 첨가하여 생리활성이 강화된 식혜를 개발하고 있다(11). 이와 관련하여 가루녹차(9), 단호박(12), 오미자(13), 오디 (11), 인삼(14), 베리류(15)를 첨가한 식혜 및 유근피 추출물 (16), 헛개나무 열매 추출물(17), 황기추출액(18), 옥수수 수염 추출액 첨가 식혜(19)와 천궁 추출액과 유색미(10)를 동시에 사용한 식혜에 관한 연구가 진행되어 있다.

본 연구에서는 생리활성이 강화된 식혜 제조를 위한 연 구의 일환으로 황해쑥의 변종이며 최근 품종보호 등록된 남해군 자생 쑥 품종인 섬애약쑥 추출물을 농도별로 첨가하 여 식혜를 제조함에 있어 당화시간에 따른 품질변화를 확인 하였다.

\section{재료 및 방법}

\section{재료 및 시료의 제조}

실험에 사용된 섬애약숙(Seomaeyaksuk, Artemisia argyi H.)은 2014년 6월경 경남 남해군 설천면에서 재배되고 있는 것을 채취하여 이물질을 제거한 후, 흐르는 물에서 2회 세척 하였다. 이를 $18-24^{\circ} \mathrm{C}$ 의 그늘지고 바람이 잘 통하는 실내에 서 매일 1 회씩 위치를 바꾸거나 뒤집어 주면서 14 일간 자연 건조 시켰다. 건조가 완료된 섬애약쑥은 비닐팩에 담아 흡 습을 방지하여 상온에 보관하면서 시료로 사용하였다.

식혜 제조를 위한 맥아는 푸른들농산(주)(Andong, Korea) 의 제품을 구입하여 균일하게 체질한 후 고운분말을 사용하 였고, 고두밥 제조는 시판되는 고성 청결미를 이용하였다.

\section{쑥 추출물의 제조}

쑥 식혜 제조에 사용된 쑥 추출물은 음건쑥 무게 대비 정제수를 10 배 가하여 2 시간 이상 침지시켜 충분히 수화시 킨 후 autoclave를 이용하여 $121^{\circ} \mathrm{C}$ 에서 30 분간 고온 추출하 였다. 추출물은 cheese cloth로 여과하여 사용하였다.
쑥 식혜의 제조

멥쌀을 정제수로 5 회 세척하여 1 시간 동안 수침하여 불 린 후 10 분간 물을 뺀 다음 무게 대비 1.2 배의 물을 가하여 고두밥을 지었다. 고두밥 각 $100 \mathrm{~g}$ 에 정제수 $500 \mathrm{~mL}$ 을 가하 고 여기에 체에 친 엿기름 가루를 총 무게 대비 $10 \%$ 첨가한 것을 대조군으로 하였다. 실험군은 대조군과 고두밥 및 엿 기름의 양은 동일하게 하고, 정제수에 쑥 추출액을 5,10 , 15 및 $20 \%$ 가 되도록 혼합한 후 최종 무게가 대조군과 동일 하도록 조절하였다. 각각의 혼합물은 $60 \pm 3^{\circ} \mathrm{C}$ 의 항온수조 내에서 내용물이 모두 잠기게 유지하면서 5 시간 동안 당화 시키면서 매 1시간마다 시료를 취하였다.

\section{탁도 및 색도}

탁도는 침출 시료 일정량을 취하여 분광광도계(Optizen ALPHA, Mecasys Co., Ltd., Daejeon, Korea)를 이용하여 $600 \mathrm{~nm}$ 에서 흡광도를 측정하였다.

색도는 시료액 일정량을 취하여 색차계(Ultra Scan VIS, Hunter Associates Laboratory Inc., Reston, VA, USA)로 측정 한 후 Hunter scale에 의한 L(lightness), a(redness), b(yellowness) 값으로 나타내었다. 각 실험군별로 5 개 이상의 시료에 대한 색도를 측정하였으며, 이 때 사용된 표준 백판의 $\mathrm{L}$ 값은 $99.71, \mathrm{a}$ 값은 $-0.15, \mathrm{~b}$ 값은 0.02 였다.

$\mathrm{pH}$

시료 $1 \mathrm{~g}$ 에 증류수를 가해 $50 \mathrm{~mL}$ 로 만들어 충분히 균질화 하여 진탕추출한 후 여과한 여액을 실험에 사용하였다. $\mathrm{pH}$ 는 $\mathrm{pH}$ meter(Model 720, Thermo Orion, Beverly, MA, USA) 를 이용하여 3 회 반복 측정하였다.

\section{가용성 고형분 및 환원당 함량}

가용성 고형분은 원심분리하여 얻은 발효 상등액을 굴절 당도계(PR-201a, Atago, Tokyo, Japan)로 측정하여 ${ }^{\circ}$ Brix로 표시하였다.

환원당은 3,5-dinitrosalicylic acid(DNS)에 의한 비색법 (20)에 따라 침출액 $1 \mathrm{~mL}$ 에 DNS 시약 $3 \mathrm{~mL}$ 을 가하고 $97^{\circ} \mathrm{C}$ 에서 15 분간 가열한 다음 빙수 중에서 냉각한 후 $570 \mathrm{~nm}$ 에 서 흡광도를 측정하였다. 환원당의 함량은 glucose(SigmaAldrich Co., Ltd., St. Louis, MO, USA)를 표준물질로 하여 작성한 표준검량곡선으로부터 산정하였다.

\section{총 폴리페놀 화합물의 함량}

총 폴리페놀 화합물의 함량은 Folin-Ciocalteu법(21)으로 측정하였다. 시료를 $2,700 \times g$ 에서 15 분간 원심분리한 후 상등액을 원 액, 10 배, 20 배, 50 배, 100 배가 되게 희석하고 희석한 액 $0.5 \mathrm{~mL}$ 을 시험관에 분주하였다. 여기에 $25 \%$ $\mathrm{Na}_{2} \mathrm{CO}_{3}$ 용액 $0.5 \mathrm{~mL}$ 을 첨가하여 3 분간 정치시켰다. 다시 $2 \mathrm{~N}$ Folin-Ciocalteu phenol 시약 $0.25 \mathrm{~mL}$ 을 첨가하여 혼합한 
다음 $30^{\circ} \mathrm{C}$ 에서 1 시간 동안 정치시켜 발색시켰다. 발색된 청색을 분광광도계를 이용하여 $750 \mathrm{~nm}$ 에서 흡광도를 측정 하였다. 이때 총 폴리페놀 화합물의 함량은 gallic acid (Sigma-Aldrich Co., Ltd.)를 이용하여 작성한 표준곡선으로 부터 산출하여 gallic acid에 상당하는 량으로 계산하였다. 각 실험은 3회 반복하여 평균값으로 나타내었다.

\section{$\mathrm{DPPH}$ 라디칼 소거활성}

Blois의 방법(22)을 변형하여 DPPH 라디칼 소거활성에 의한 항산화 활성을 측정하였다. 에탄올로 $1.5 \times 10^{-4} \mathrm{M}$ 농도 가 되도록 조절한 $\mathrm{DPPH}$ (1,1-diphenyl-2-picryhdrazyl, $\mathrm{C}_{18} \mathrm{H}_{12} \mathrm{~N}_{5} \mathrm{O}_{6}$ )용액 $0.8 \mathrm{~mL}$ 에 $13,000 \mathrm{rpm}$ 로 3 분간 원심분리한 시료 상등액 $0.2 \mathrm{~mL}$ 를 가하고 10 초간 균질화 시킨 다음 실온에서 30 분간 방치한 후 분광광도계로 $525 \mathrm{~nm}$ 에서 흡광 도를 측정하였다. 음성대조군은 시료 대신에 증류수 0.2 $\mathrm{mL}$ 를 가하여 동일하게 실험하였다. DPPH 라디칼 소거 활 성은 실험구와 음성대조구의 흡광도를 구하여 시료 첨가군 대비 무첨가군의 흡광도 비로부터 계산하여 백분율(\%)로 표시하였다. 각 실험은 3 회 반복하여 평균값으로 나타내었 다.

\section{관능검사}

당화가 완료된 섬애약쑥 식혜의 관능검사는 경남과학기 술대학교 남녀 학생 25 명을 대상으로 실시하였다. 평가 특 성에 대한 식별력과 강도에 대한 판단 기준을 확립한 후 상온에서 30 분 정도 보관하여 온도를 동일하게 조절한 식 혜를 $50 \mathrm{~mL}$ 씩 종이컵에 담아 제공하였다. 관능검사는 색, 쑥 향, 감미도, 밥알의 퍼짐성, 전반적인 기호도를 항목 당 7점 만점으로 평가하였다. 각 항목에 대해 기호도가 낮을수 록 낮은 점수를 부여하고 기호도가 높을수록 높은 점수를 부여하도록 하였다.

\section{통계처리}

모든 실험은 5 회 이상 반복하여 실시하였으며 실험으로 부터 얻은 결과는 SPSS 12.0(IBM, Armonk, NY, USA)을 사용하여 분석하였다. 결과치는 실험군당 평균표표준편차 로 표시하였고, 통계적 유의성 검정은 일원배치 분산분석 (one-way analysis of variance)을 한 후 $\mathrm{p}<0.05$ 수준에서 Duncan's multiple range test를 시행하였다.

\section{결과 및 고찰}

섬애약숙 추출물의 품질특성

그늘에서 건조한 쑥과 증류수를 1:10으로 혼합하여 충분 히 수화시킨 후 autoclave를 이용해 $121^{\circ} \mathrm{C}$ 에서 30 분간을 추출한 후 여과한 쑥 추출물의 이화학적 특성을 분석한
결과는 Table 1 과 같다. 쑥 추출액의 가용성 고형분 함량은 $4.00{ }^{\circ} \mathrm{Brix}$ 였고, $\mathrm{pH}$ 는 6.22 로 중성에 가까웠으며, 산도는 $0.15 \%$ 였다. 탁도는 1.08 로 높았고, 환원당의 함량은 0.04 $\mathrm{mg} / 100 \mathrm{~g}$ 에 불과하였다.

Table 1. Physicochemical characteristics of water extracts from shadow dried Seomaeyaksuk

\begin{tabular}{cc}
\hline Items & Contents \\
\hline Soluble solid ( ${ }^{\circ}$ Brix) & $4.00 \pm 0.00^{1)}$ \\
$\mathrm{pH}$ & $6.22 \pm 0.02$ \\
Acidity (\%) & $0.15 \pm 0.03$ \\
Tubidity (OD value) & $1.08 \pm 0.00$ \\
Reducing sugar (mg/100 g) & $0.04 \pm 0.00$ \\
\hline
\end{tabular}

${ }^{1)}$ Each value is a mean $\pm \mathrm{SD}$ of 5 samples.

탁 도

식혜 제조시 섬애약쑥 추출물의 적정 첨가 비율을 확인 하고자 섬애약쑥 추출물을 첨가하지 않고, 맥아분말과 물 을 혼합한 것을 대조군(0\%)으로 하고, 쑥 추출물을 5,10 , 15 및 $20 \%$ 씩 첨가하여 각각 제조한 식혜의 당화 시간별 탁도를 분석한 결과는 Table 2와 같다.

섬애약쑥 식혜의 당화시간별 탁도는 쑥 추출물의 첨가비 율에 따라 절대 값에는 차이가 있었으나 당화시간 2 시간까 지는 증가하였다가 그 이후부터는 감소하는 동일한 경향을 나타내었다. 즉, 섬애약쑥 추출물을 첨가하지 않은 대조군 의 경우 탁도는 당화 전 흡광도 값이 0.24 이던 것이 당화 1 시간 만에 최고치를 나타내어 0.83 의 흡광도 값을 나타내 었고, 당화 2시간에는 0.89 로 높아졌으나 그 이후부터는 점차 감소하는 경향을 보여 당화 5 시간에는 당화전과 유사 한 범위였다. 섬애약쑥 추출물을 첨가한 시료에서는 추출 물의 첨가량이 많아질수록 탁도도 증가하였으며, $5 \%$ 와 $10 \%$ 첨가군의 경우 당화 전에 비해 1 시간 후에 탁도가 2 배 정도 증가한데 반해 $15 \%$ 와 $20 \%$ 첨가군의 경우 당화 1 시간까지는 차이가 없다가 당화 2시간에 최고치를 보인 후 흡광도 값이 감소하였고 당화 5 시간에는 당화 전에 비해 흡광도 값이 더 낮았다.

탁도는 액체의 흐림 정도를 나타내는 지표로 사용되며 식혜의 액은 일반적으로 맑고 투명해야 하는데, 팽화미분 을 첨가하여 제조한 식혜의 탁도는 팽화미분이 빠르게 분해 및 분산되어 고형물의 양이 늘어나기 때문에 팽화미분의 첨가량이 증가할수록, 당화기간이 길어질수록 더 높아졌다 고 보고되어 있다(23). 천궁 추출물을 첨가한 식혜의 경우 천궁 추출물의 첨가량이 많을수록 탁도는 높았는데 이는 천궁 추출물의 첨가에 따른 고형물의 증가 때문이라는 $\mathrm{Kim}$ 과 Park의 보고(24)가 있다. 이들의 연구결과와 본 연구의 결과를 비교해 볼 때 섬애약쑥 추출물의 첨가 비율이 높을 수록 탁도가 증가한 것은 섬애약쑥 추출물에 존재하는 고형 
분의 영향인 것으로 판단되며, 섬애약쑥 추출물이 일정 농 도 이상이 되면서 당화효소의 작용을 저해하여 $15 \%$ 와 $20 \%$ 첨가군의 초기 탁도 증가가 낮았던 것으로 추정되는데, 이 에 대해서는 효소활성과 관련한 연구의 추가 진행이 필요할 것으로 판단된다.

색 도

섬애약숙 추출물을 0-20\%까지 첨가하여 제조한 식혜의 당화 시간별 색도 변화를 분석한 결과는 Table 3 과 같다. 명도(L)는 당화 전에는 34.17-36.40으로 섬애약쑥 추출액의 첨가 비율이 높을수록 더 낮아지는 경향이었으며, 당화시 간이 경과함에 따라 미량씩 감소하는 경향을 나타내어 당화
5시간에는 32.18-32.69로 대조군 및 실험군간에 유의적인 차이가 없었다. 적색도는 섬애약쑥 추출물의 첨가량이 높 을수록 더 높았고, 당화시간이 경과할수록 더 높아지는 경 향이었다. 당화 전에 비해 5 시간 후에 대조군의 적색도는 0.15 이던 것이 0.57 로 증가하였고, 섬애약쑥 추출액을 $20 \%$ 첨가하였을 때는 0.66 에서 2.11로 증가하였다. 황색도도 적색도와 동일한 경향이었으나 적색도가 섬애약쑥 추출액 의 첨가 비율에 따라 시료간에 차이가 큰 반면 황색도는 시료간의 유의차가 적었다. 대조군과 섬애약쑥 추출액 $5 \%$ 첨가군의 경우 당화 전의 황색도는 각각 4.07 과 4.04 로 유의 차가 없었으나 당화 5 시간 후에는 각각 6.98 과 7.24 로 5\% 첨가군에서 더 높았다.

Table 2. Changes in turbidity during saccharification of Sikhye added with Seomaeyaksuk extract

(OD value)

\begin{tabular}{|c|c|c|c|c|c|c|}
\hline \multirow{2}{*}{$\begin{array}{l}\text { Addition ratio of } \\
\text { mugwort extract (\%) }\end{array}$} & \multicolumn{6}{|c|}{ Saccharification time (h) } \\
\hline & 0 & 1 & 2 & 3 & 4 & 5 \\
\hline 0 & $0.24 \pm 0.00^{1 / 22(B 3)}$ & $0.83 \pm 0.03^{\mathrm{dD}}$ & $0.89 \pm 0.00^{\mathrm{eD}}$ & $0.64 \pm 0.02^{\mathrm{cD}}$ & $0.36 \pm 0.00^{\mathrm{bB}}$ & $0.23 \pm 0.00^{\mathrm{aA}}$ \\
\hline 5 & $0.13 \pm 0.00^{\mathrm{aA}}$ & $0.24 \pm 0.02^{\mathrm{bA}}$ & $1.19 \pm 0.02^{\mathrm{eE}}$ & $0.64 \pm 0.01^{\mathrm{dD}}$ & $0.35 \pm 0.01^{\mathrm{CB}}$ & $0.25 \pm 0.00^{6 \mathrm{~B}}$ \\
\hline 10 & $0.30 \pm 0.00^{\mathrm{bC}}$ & $0.55 \pm 0.02^{\mathrm{dB}}$ & $0.57 \pm 0.01^{\mathrm{eA}}$ & $0.34 \pm 0.00^{\mathrm{cA}}$ & $0.30 \pm 0.01^{\mathrm{bA}}$ & $0.26 \pm 0.01^{\mathrm{aB}}$ \\
\hline 15 & $0.52 \pm 0.01^{\mathrm{d}}$ & $0.55 \pm 0.00^{\mathrm{eB}}$ & $0.64 \pm 0.00^{\mathrm{fB}}$ & $0.43 \pm 0.00^{\mathrm{CB}}$ & $0.30 \pm 0.01^{\mathrm{bA}}$ & $0.25 \pm 0.00^{\mathrm{aB}}$ \\
\hline 20 & $0.63 \pm 0.00^{\mathrm{dE}}$ & $0.65 \pm 0.00^{\mathrm{eC}}$ & $0.74 \pm 0.00^{\mathrm{fC}}$ & $0.59 \pm 0.0^{\mathrm{cC}}$ & $0.44 \pm 0.00^{\mathrm{bC}}$ & $0.36 \pm 0.01^{\mathrm{aC}}$ \\
\hline
\end{tabular}

${ }^{1)}$ Each value is a mean \pm SD of 5 samples.

${ }^{2) \mathrm{a}-\mathrm{f}}$ Means with different letters in the same row are significantly different at $\mathrm{p}<0.05$ by Duncan's multiple range test.

${ }^{3) A-E}$ Means with different letters in the same column are significantly different at $p<0.05$ by Duncan's multiple range test.

Table 3. Changes in Hunter's color value during saccharification of Sikhye added with Seomaeyaksuk extract

\begin{tabular}{|c|c|c|c|c|c|c|c|}
\hline \multirow{2}{*}{ Item } & \multirow{2}{*}{$\begin{array}{l}\text { Addition ratio of } \\
\text { mugwort extract (\%) }\end{array}$} & \multicolumn{6}{|c|}{ Saccharification time (h) } \\
\hline & & 0 & 1 & 2 & 3 & 4 & 5 \\
\hline \multirow{5}{*}{$\mathrm{L}$} & 0 & $36.08 \pm 0.28^{1 /(2)(3)}$ & $34.46 \pm 0.95^{\mathrm{bA}}$ & $33.45 \pm 0.03^{\mathrm{aA}}$ & $33.54 \pm 0.04^{\mathrm{aB}}$ & $32.83 \pm 0.42^{\mathrm{aA}}$ & $32.69 \pm 0.35^{\mathrm{aA}}$ \\
\hline & 5 & $36.40 \pm 0.48^{\mathrm{eD}}$ & $34.08 \pm 0.71^{\mathrm{dA}}$ & $33.95 \pm 0.01^{\mathrm{cdB}}$ & $33.44 \pm 0.04^{\mathrm{bcB}}$ & $32.84 \pm 0.08^{\mathrm{abA}}$ & $32.43 \pm 0.04^{\mathrm{aA}}$ \\
\hline & 10 & $35.59 \pm 0.03^{\mathrm{dC}}$ & $34.29 \pm 0.04^{\mathrm{cA}}$ & $33.86 \pm 0.03^{\mathrm{CB}}$ & $32.91 \pm 0.32^{\mathrm{bA}}$ & $32.69 \pm 0.64^{\mathrm{abA}}$ & $32.18 \pm 0.32^{\mathrm{aA}}$ \\
\hline & 15 & $34.96 \pm 0.03^{\mathrm{fB}}$ & $34.40 \pm 0.01^{\mathrm{eA}}$ & $34.13 \pm 0.18^{\mathrm{dC}}$ & $33.01 \pm 0.14^{\mathrm{bA}}$ & $33.91 \pm 0.04^{\mathrm{cB}}$ & $32.39 \pm 0.13^{\mathrm{aA}}$ \\
\hline & 20 & $34.17 \pm 0.06^{\mathrm{cA}}$ & $34.46 \pm 0.02^{\mathrm{cA}}$ & $34.25 \pm 0.03^{\mathrm{cC}}$ & $33.53 \pm 0.03^{\mathrm{bB}}$ & $32.30 \pm 0.14^{\mathrm{aA}}$ & $32.28 \pm 0.52^{\mathrm{aA}}$ \\
\hline \multirow{5}{*}{$\mathrm{a}$} & 0 & $0.15 \pm 0.03^{\mathrm{aA}}$ & $0.20 \pm 0.03^{\mathrm{abA}}$ & $0.27 \pm 0.01^{\mathrm{bcA}}$ & $0.29 \pm 0.06^{\mathrm{cA}}$ & $0.34 \pm 0.01^{\mathrm{cA}}$ & $0.57 \pm 0.09^{\mathrm{dA}}$ \\
\hline & 5 & $0.26 \pm 0.03^{\mathrm{aB}}$ & $0.32 \pm 0.05^{\mathrm{abB}}$ & $0.37 \pm 0.01^{\mathrm{bB}}$ & $0.41 \pm 0.04^{\mathrm{bB}}$ & $0.57 \pm 0.12^{\mathrm{cB}}$ & $0.62 \pm 0.02^{\mathrm{cA}}$ \\
\hline & 10 & $0.41 \pm 0.04^{\mathrm{aC}}$ & $0.43 \pm 0.02^{\mathrm{aC}}$ & $0.55 \pm 0.01^{\mathrm{bC}}$ & $0.65 \pm 0.06^{\mathrm{CC}}$ & $0.79 \pm 0.05^{\mathrm{dC}}$ & $0.96 \pm 0.03^{\mathrm{eC}}$ \\
\hline & 15 & $0.44 \pm 0.03^{\mathrm{aC}}$ & $0.52 \pm 0.00^{6 D}$ & $0.55 \pm 0.01^{\mathrm{bC}}$ & $0.70 \pm 0.02^{\mathrm{cC}}$ & $0.73 \pm 0.02^{\mathrm{cdC}}$ & $0.75 \pm 0.01^{\mathrm{dB}}$ \\
\hline & 20 & $0.66 \pm 0.01^{\mathrm{aD}}$ & $0.81 \pm 0.01^{\mathrm{bE}}$ & $1.17 \pm 0.03^{\mathrm{cD}}$ & $1.60 \pm 0.01^{\mathrm{dD}}$ & $2.09 \pm 0.02^{\mathrm{eD}}$ & $2.11 \pm 0.11^{\mathrm{eD}}$ \\
\hline \multirow{5}{*}{$\mathrm{b}$} & 0 & $4.07 \pm 0.03^{\mathrm{aA}}$ & $4.96 \pm 0.03^{\mathrm{bB}}$ & $5.31 \pm 0.47^{\mathrm{bcA}}$ & $5.59 \pm 0.12^{\mathrm{cdA}}$ & $5.86 \pm 0.28^{\mathrm{dA}}$ & $6.98 \pm 0.13^{\mathrm{eA}}$ \\
\hline & 5 & $4.04 \pm 0.09^{\mathrm{aA}}$ & $4.75 \pm 0.14^{\mathrm{bA}}$ & $5.28 \pm 0.02^{\mathrm{cA}}$ & $5.80 \pm 0.06^{\mathrm{dAB}}$ & $7.06 \pm 0.66^{\mathrm{eB}}$ & $7.24 \pm 0.05^{\mathrm{eB}}$ \\
\hline & 10 & $4.66 \pm 0.04^{\mathrm{aB}}$ & $5.31 \pm 0.06^{\mathrm{bC}}$ & $5.82 \pm 0.23^{\mathrm{cB}}$ & $6.04 \pm 0.24^{\mathrm{cB}}$ & $7.23 \pm 0.32^{\mathrm{dB}}$ & $7.53 \pm 0.06^{\mathrm{dC}}$ \\
\hline & 15 & $5.91 \pm 0.03^{\mathrm{aC}}$ & $5.97 \pm 0.07^{\mathrm{aD}}$ & $6.09 \pm 0.07^{\mathrm{aB}}$ & $6.41 \pm 0.30^{\mathrm{aC}}$ & $7.33 \pm 0.56^{6 \mathrm{~B}}$ & $7.73 \pm 0.15^{b C}$ \\
\hline & 20 & $5.97 \pm 0.06^{\mathrm{aC}}$ & $6.14 \pm 0.02^{\mathrm{abE}}$ & $6.68 \pm 0.04^{\mathrm{bcC}}$ & $7.20 \pm 0.02^{\mathrm{cD}}$ & $8.77 \pm 0.31^{\mathrm{dC}}$ & $9.21 \pm 0.08^{\mathrm{eD}}$ \\
\hline
\end{tabular}

${ }^{1)}$ Each value is a mean \pm SD of 5 samples.

${ }^{2) a-5}$ Means with different letters in the same row are significantly different at $p<0.05$ by Duncan's multiple range test.

${ }^{3) \mathrm{A}-\mathrm{E}}$ Means with different letters in the same column are significantly different at $\mathrm{p}<0.05$ by Duncan's multiple range test. 
본 연구의 결과는 황기 추출액을 첨가한 식혜에서 명도 값은 당화 초기에는 황기 추출액 첨가량에 따른 유의적인 차이가 없었으나 당화가 진행됨에 따라 감소하였고, 적색 도와 황색도는 황기 추출물 첨가량이 높을수록 더 높았으 며, 당화시간이 증가함에 따라 유의적으로 증가하였다는 보고(18)와 일치하는 경향이었다.

팽화미분을 비율별로 첨가한 식혜의 명도값은 당화 1 시 간 이후부터는 감소하고, 적색도와 황색도는 팽화미분의 첨가량이 증가할수록 높았고 시간이 경과할수록 증가하였 는데, 이는 당화시간의 경과에 따른 Maillard 반응의 결과라 고 보고되어 있다(23). 커피박 열수추출물을 첨가하여 제조 한 식혜에서도 적색도와 황색도는 대조구보다 더 높았으 며, 커피박 열수추출물의 비율이 많아질수록 더 높았고 당 화시간이 경과할수록 더 높아졌는데 이는 커피 추출액 고유 의 색도가 식혜의 색에 영향을 미첬기 때문으로 추정하였다 (25). 본 연구의 결과에서 섬애약쑥 추출물의 혼합 비율이 높아질수록 적색도와 황색도가 모두 높아지는 것도 섬애약 쑥 추출물 자체의 색이 영향을 미쳤기 때문으로 판단되며, 당화 과정 중에 열에 의해 식혜액 중의 당분들과의 반응 및 갈변화의 진행으로 인해 그 값이 점차 더 증가하는 것으 로 생각된다.
$\mathrm{pH}$

Table 4와 같이 섬애약쑥 추출물을 첨가한 식혜의 당화 전 $\mathrm{pH}$ 는 쑥 추출물을 첨가하지 않은 대조군이 5.42 로 가장 낮았고, 섬애약쑥 추출물 $10-20 \%$ 첨가군의 $\mathrm{pH}$ 는 5.62 로 유의적인 차이가 없었다. 당화시간이 경과하면서 $\mathrm{pH}$ 는 점 차 높아지는 경향을 보였는데, 당화 5 시간 후 대조군의 $\mathrm{pH}$ 는 5.56으로 증가하였고, 섬애약쑥 추출물 첨가군의 $\mathrm{pH}$ 는 5.68-5.73으로 증가하였다. 이러한 결과는 식혜 제조시 첨 가한 황기 추출물의 양이 많아질수록 $\mathrm{pH}$ 는 증가하는 경향 을 보여 당화 전 황기 추출물 무첨가군의 $\mathrm{pH}$ 가 5.39일 때 $100 \%$ 첨가군의 $\mathrm{pH}$ 는 5.57 였고, 당화 5 시간 후에는 각각 5.54 와 5.80 으로 증가하였다는 보고(18)와 일치하는 경향이 었다.

$\operatorname{Kim}$ 등(17)은 헛개나무 열매의 $\mathrm{pH}$ 가 일반 식혜의 $\mathrm{pH}$ 보 다 낮기 때문에 식혜 제조시 헛개나무 열매 추출물의 첨가 량이 많아질수록 식혜의 $\mathrm{pH}$ 는 낮았는데, 이는 헛개나무 열매 추출물 속의 유기산이 영향을 미치기 때문이라고 추정 하였다. 본 연구에서는 섬애약쑥 추출물의 $\mathrm{pH}$ 가 6.22로 상 대적으로 높아 섬애약쑥 추출물이 첨가됨으로써 식혜의 $\mathrm{pH}$ 가 대조군에 비해 오히려 더 높은 것으로 생각된다.

Table 4. Changes in $\mathrm{pH}$ during saccharification of Sikhye added with Seomaeyaksuk extract

\begin{tabular}{|c|c|c|c|c|c|c|}
\hline \multirow{2}{*}{$\begin{array}{c}\text { Addition ratio of } \\
\text { mugwort extract (\%) }\end{array}$} & \multicolumn{6}{|c|}{ Saccharification time (h) } \\
\hline & 0 & 1 & 2 & 3 & 4 & 5 \\
\hline 0 & $5.42 \pm 0.01^{1 \mathrm{~b} 2) \mathrm{A} 3)}$ & $5.37 \pm 0.01^{\mathrm{aA}}$ & $5.44 \pm 0.01^{\mathrm{bA}}$ & $5.47 \pm 0.00^{\mathrm{bA}}$ & $5.52 \pm 0.00^{\mathrm{cA}}$ & $5.56 \pm 0.01^{\mathrm{dA}}$ \\
\hline 5 & $5.60 \pm 0.00^{\mathrm{aB}}$ & $5.63 \pm 0.01^{\mathrm{bB}}$ & $5.63 \pm 0.01^{\mathrm{bB}}$ & $5.65 \pm 0.01^{\mathrm{bB}}$ & $5.69 \pm 0.03^{\mathrm{cB}}$ & $5.72 \pm 0.00^{\mathrm{dB}}$ \\
\hline 10 & $5.62 \pm 0.01^{\mathrm{aC}}$ & $5.62 \pm 0.01^{\mathrm{B}}$ & $5.62 \pm 0.00^{\mathrm{aB}}$ & $5.65 \pm 0.01^{\mathrm{bB}}$ & $5.67 \pm 0.01^{\mathrm{cB}}$ & $5.68 \pm 0.00^{\mathrm{cB}}$ \\
\hline 15 & $5.62 \pm 0.01^{\mathrm{aC}}$ & $5.66 \pm 0.02^{\mathrm{bC}}$ & $5.67 \pm 0.00^{\mathrm{bcC}}$ & $5.68 \pm 0.00^{\mathrm{ddC}}$ & $5.69 \pm 0.01^{\mathrm{dB}}$ & $5.71 \pm 0.00^{\mathrm{eB}}$ \\
\hline 20 & $5.62 \pm 0.01^{\mathrm{aC}}$ & $5.66 \pm 0.01^{\mathrm{bC}}$ & $5.67 \pm 0.01^{\mathrm{bcC}}$ & $5.68 \pm 0.00^{\mathrm{cC}}$ & $5.68 \pm 0.00^{\mathrm{cB}}$ & $5.73 \pm 0.01^{\mathrm{dB}}$ \\
\hline
\end{tabular}

${ }^{1)}$ Each value is a mean \pm SD of 5 samples.

2)a-e Means with different letters in the same row are significantly different at $p<0.05$ by Duncan's multiple range test.

${ }^{3) A-E}$ Means with different letters in the same column are significantly different at $p<0.05$ by Duncan's multiple range test.

Table 5. Changes in soluble solid during saccharification of Sikhye added with Seomaeyaksuk extract

$\left({ }^{\circ}\right.$ Brix $)$

\begin{tabular}{|c|c|c|c|c|c|c|}
\hline \multirow{2}{*}{$\begin{array}{l}\text { Addition ratio of } \\
\text { mugwort extract (\%) }\end{array}$} & \multicolumn{6}{|c|}{ Saccharification time (h) } \\
\hline & 0 & 1 & 2 & 3 & 4 & 5 \\
\hline 0 & $2.80 \pm 0.00^{1 / 122) A 3)}$ & $7.93 \pm 0.07^{\mathrm{bC}}$ & $10.57 \pm 0.06^{\mathrm{cD}}$ & $11.10 \pm 0.10^{\mathrm{dA}}$ & $11.57 \pm 0.01^{\mathrm{eA}}$ & $12.95 \pm 0.07^{\mathrm{fB}}$ \\
\hline 5 & $2.80 \pm 0.00^{\mathrm{aA}}$ & $7.20 \pm 0.00^{\mathrm{bA}}$ & $10.47 \pm 0.06^{\mathrm{cD}}$ & $11.33 \pm 0.06^{\mathrm{dB}}$ & $12.00 \pm 0.00^{\mathrm{BC}}$ & $12.55 \pm 0.07^{\mathrm{fA}}$ \\
\hline 10 & $3.00 \pm 0.00^{\mathrm{aA}}$ & $7.35 \pm 0.07^{\mathrm{bB}}$ & $9.33 \pm 0.02^{\mathrm{cB}}$ & $11.83 \pm 0.02^{\mathbb{d}}$ & $12.07 \pm 0.06^{\mathrm{CC}}$ & $12.93 \pm 0.06^{\mathrm{fB}}$ \\
\hline 15 & $3.10 \pm 0.00^{\mathrm{aA}}$ & $7.20 \pm 0.00^{\mathrm{bA}}$ & $9.76 \pm 0.00^{\mathrm{cC}}$ & $11.71 \pm 0.06^{\mathrm{dC}}$ & $11.93 \pm 0.06^{\mathrm{eB}}$ & $13.50 \pm 0.00^{\mathrm{fC}}$ \\
\hline 20 & $3.20 \pm 0.00^{\mathrm{aA}}$ & $7.30 \pm 0.00^{\mathrm{bB}}$ & $9.13 \pm 0.02^{\mathrm{cA}}$ & $12.47 \pm 0.06^{\mathrm{dE}}$ & $13.47 \pm 0.06^{\mathrm{eD}}$ & $14.07 \pm 0.00^{\mathrm{fD}}$ \\
\hline
\end{tabular}

${ }^{1)}$ Each value is a mean \pm SD of 5 samples.

${ }^{2) a-f}$ Means with different letters in the same row are significantly different at $p<0.05$ by Duncan's multiple range test.

${ }^{3) A-E}$ Means with different letters in the same column are significantly different at $p<0.05$ by Duncan's multiple range test. 


\section{가용성 고형분}

섬애약쑥 추출액을 첨가한 식혜의 가용성 고형분은 쑥 추출액의 첨가량이 많을수록, 당화시간이 경과할수록 증가 하는 경향이었다(Table 5). 당화 전의 가용성 고형분은 2.80-3.20 ${ }^{\circ} \mathrm{Brix}$ 의 범위이던 것이 당화 2 시간 후에는 당화 초기에 비해 약 2.9-3.8배 증가하여 9.13-10.57 ${ }^{\circ} \mathrm{Brix}$ 의 범위 였다. 섬애약쑥 추출물 $20 \%$ 첨가군의 경우 당화 2 시간에는 시료 중 가용성 고형분이 가장 낮았으나 당화 5 시간까지 지속적으로 증가하여 최종 $14.07{ }^{\circ} \mathrm{Brix}$ 로 가장 높았다. 여타 실험군들의 가용성 고형분도 당화시간의 경과와 더불어 유의적으로 증가하여 당화 5 시간 후에는 $12.55-13.50{ }^{\circ} \mathrm{Brix}$ 의 범위였다.

오디를 $30 \%$ 까지 첨가한 식혜의 경우 당화 4 시간까지는 고형분 함량이 증가하지만 그 이후부터는 증가폭이 적어지 면서 당화 5 시간 이후부터는 거의 차이가 없어 적정 당화 시간은 4-5시간이라고 보고되어 있다(11). Kang 등(26)은 마늘 식혜의 경우 가용성 고형분은 마늘의 첨가량이 많을수 록 당화 시간이 경과할수록 더 높았는데, 이는 식혜의 당화 가 진행되면서 당화효소에 의해 전분이 분해되기 때문으로 식혜 제조시 첨가한 밥의 양과 엿기름 당화액을 추출하는데 사용된 엿기름의 양에 따라 차이를 나타낸다고 하였다. 이
들 보고와 본 연구의 결과를 비교해 볼 때 당화 4 시간 이후 부터는 당화가 완료되어 가용성 고형분의 차이가 적었고, 시료의 첨가 비율이 많을수록, 당화 시간이 경과할수록 가 용성 고형분이 더 높은 것은 일치하는 경향이었다.

환원당

환원당은 단당류와 이당류 중 반응성이 있는 케톤기나 알데히드기를 갖고 있는 금속 알칼리 용액을 환원시키는 성질이 있는 것으로 환원당과 비환원당을 모두 합한 값인 총당의 변화와 유사한 경향을 나타내는 것으로 알려져 있다 $(27,28)$.

섬애약쑥 추출물을 0-20\%까지 첨가하여 제조한 식혜의 당화시간별 환원당의 함량을 분석한 결과는 Table 6과 같이 당화시간이 경과함에 따라 증가하였다. 당화초기 환원당의 함량은 섬애약쑥 추출물 $15 \%$ 와 $20 \%$ 첨가한 군에서 각각 $1.17 \mathrm{~g} / 100 \mathrm{~mL}$ 와 $1.15 \mathrm{~g} / 100 \mathrm{~mL}$ 로 유의적으로 높았고, 섬애 약쑥 추출물을 $5 \%$ 첨가한 군과 대조군은 각각 $0.75 \mathrm{~g} / 100$ $\mathrm{mL}$ 와 $0.73 \mathrm{~g} / 100 \mathrm{~mL}$ 로 유의차가 없었다. 당화가 진행됨에 따라 환원당의 함량은 증가하는 경향을 나타내었는데 당화 1시간에 가장 증가폭이 커서 당화전에 비해 약 5.5-9배 더 증가하여 $6.32-7.25 \mathrm{~g} / 100 \mathrm{~mL}$ 의 범위였다. 그 후에도 당화시

Table 6. Changes in reducing sugar during saccharification of Sikhye added with Seomaeyaksuk extract

$(\mathrm{g} / 100 \mathrm{~mL})$

\begin{tabular}{|c|c|c|c|c|c|c|}
\hline \multirow{2}{*}{$\begin{array}{l}\text { Addition ratio of } \\
\text { mugwort extract (\%) }\end{array}$} & \multicolumn{6}{|c|}{ Saccharification time (h) } \\
\hline & 0 & 1 & 2 & 3 & 4 & 5 \\
\hline 0 & $0.75 \pm 0.02^{1) 22(A 3)}$ & $6.57 \pm 0.05^{\mathrm{bB}}$ & $8.09 \pm 0.05^{\mathrm{cA}}$ & $10.50 \pm 0.01^{\mathrm{dA}}$ & $11.71 \pm 0.04^{\mathrm{eA}}$ & $12.33 \pm 0.03^{\mathrm{fA}}$ \\
\hline 5 & $0.73 \pm 0.02^{\mathrm{aA}}$ & $6.59 \pm 0.02^{\mathrm{bB}}$ & $8.13 \pm 0.03^{\mathrm{cA}}$ & $10.57 \pm 0.01^{\mathrm{dB}}$ & $12.03 \pm 0.04^{\mathrm{eB}}$ & $12.63 \pm 0.02^{\mathrm{fB}}$ \\
\hline 10 & $1.11 \pm 0.01^{\mathrm{aB}}$ & $6.32 \pm 0.03^{\mathrm{bA}}$ & $9.11 \pm 0.03^{\mathrm{cB}}$ & $11.14 \pm 0.03^{\mathrm{dC}}$ & $12.24 \pm 0.04^{\mathrm{eC}}$ & $12.62 \pm 0.04^{\mathrm{fB}}$ \\
\hline 15 & $1.17 \pm 0.02^{\mathrm{aC}}$ & $6.43 \pm 0.15^{\mathrm{bA}}$ & $9.73 \pm 0.01^{\mathrm{cC}}$ & $11.24 \pm 0.02^{\mathbb{d}}$ & $12.47 \pm 0.04^{\mathrm{eD}}$ & $12.91 \pm 0.06^{\mathrm{fC}}$ \\
\hline 20 & $1.15 \pm 0.02^{\mathrm{aC}}$ & $7.25 \pm 0.03^{\mathrm{bC}}$ & $9.77 \pm 0.02^{\mathrm{CC}}$ & $11.91 \pm 0.04^{\mathrm{dE}}$ & $12.78 \pm 0.04^{\mathrm{eE}}$ & $13.24 \pm 0.05^{\mathrm{fD}}$ \\
\hline
\end{tabular}

${ }^{1)}$ Each value is a mean $\pm \mathrm{SD}$ of 5 samples.

${ }^{2) \text { at }}$ Means with different letters in the same row are significantly different at $p<0.05$ by Duncan's multiple range test.

${ }^{3) A-E}$ Means with different letters in the same column are significantly different at $p<0.05$ by Duncan's multiple range test.

Table 7. Changes in total polyphenol compounds during saccharification of Sikhye added with Seomaeyaksuk extract

$(\mathrm{mg} / \mathrm{mL})$

\begin{tabular}{ccccccc}
\hline $\begin{array}{c}\text { Mixture ration of mugwort } \\
\text { extract }(\%)\end{array}$ & \multicolumn{5}{c}{ Saccharification time (h) } \\
\cline { 2 - 7 } & 0 & 1 & 2 & 3 & 4 & 5 \\
\hline 0 & $6.76 \pm 0.03^{1 / 22) \mathrm{A})}$ & $9.25 \pm 0.02^{\mathrm{cA}}$ & $7.04 \pm 0.08^{\mathrm{bA}}$ & $9.27 \pm 0.04^{\mathrm{cA}}$ & $10.43 \pm 0.09^{\mathrm{dA}}$ & $10.59 \pm 0.04^{\mathrm{eA}}$ \\
5 & $9.39 \pm 0.05^{\mathrm{aB}}$ & $10.51 \pm 0.02^{\mathrm{bB}}$ & $11.78 \pm 0.07^{\mathrm{BB}}$ & $12.93 \pm 0.03^{\mathrm{dB}}$ & $13.06 \pm 0.06^{\mathrm{B}}$ & $14.21 \pm 0.06^{\mathrm{fB}}$ \\
10 & $12.36 \pm 0.04^{\mathrm{aC}}$ & $13.27 \pm 0.12^{\mathrm{bC}}$ & $13.52 \pm 0.09^{\mathrm{cC}}$ & $14.13 \pm 0.01^{\mathrm{dC}}$ & $20.52 \pm 0.04^{\mathrm{CC}}$ & $24.70 \pm 0.10^{\mathrm{fC}}$ \\
15 & $14.13 \pm 0.02^{\mathrm{aD}}$ & $17.60 \pm 0.11^{\mathrm{bD}}$ & $19.03 \pm 0.10^{\mathrm{cD}}$ & $20.66 \pm 0.16^{\mathrm{dD}}$ & $24.36 \pm 0.08^{\mathrm{eD}}$ & $27.65 \pm 0.17^{\mathrm{fD}}$ \\
20 & $17.45 \pm 0.16^{\mathrm{aE}}$ & $18.61 \pm 0.03^{\mathrm{bE}}$ & $19.17 \pm 0.01^{\mathrm{CD}}$ & $22.11 \pm 0.10^{\mathrm{dE}}$ & $27.83 \pm 0.14^{\mathrm{EE}}$ & $29.80 \pm 0.03^{\mathrm{EE}}$ \\
\hline
\end{tabular}

\footnotetext{
${ }^{1)}$ Each value is a mean \pm SD of 5 samples.

2)a-t Means with different letters in the same row are significantly different at $p<0.05$ by Duncan's multiple range test.

${ }^{3) A-E}$ Means with different letters in the same column are significantly different at $p<0.05$ by Duncan's multiple range test.
} 
간이 경과할수록 환원당의 함량은 지속적으로 증가하여 당화 5시간 후에는 $12.33-13.24 \mathrm{~g} / 100 \mathrm{~mL}$ 이었다. 섬애약쑥 추출물을 $10 \%$ 이상 첨가하였을 때 당화 완료 후 환원당 함량은 쑥 추출액의 첨가 비율이 높을수록 유의적으로 더 높았다.

이러한 결과는 황기 추출물 첨가 식혜의 환원당량은 황 기 추출물의 첨가량이 증가할수록, 당화시간이 경과할수록 높아졌으며 황기의 첨가량이 많을수록 그 증가폭도 더 컸다 는 보고(18)와 일치하는 경향이었다. 이는 당화가 진행되면 서 amylase 효소 작용으로 가용성 고형분의 함량이 증가하 는 것과도 일치하는 경향으로 당화와 고두밥 중의 전분 분해와 더불어 첨가된 섬애약쑥 추출물로부터 분해되어 용출된 물질들이 동시에 영향을 미치기 때문으로 추정된 다. 커피박 열수추출액을 첨가한 식혜에서도 환원당은 커 피박 추출액의 첨가 비율이 높을수록, 당화시간이 경과할 수록 증가하였는데, 이는 식혜의 원료인 쌀 중의 전분이 amylase의 작용으로 분해되어 식혜 액으로 용출되었기 때 문이라고 보고되어 있다(25).

식혜에서 glucose와 fructose는 엿기름으로부터 기인하는 단맛을 내며, maltose는 식혜 특유의 시원한 단맛을 제공하 는데, 당화조건에 따라 환원당이 분해되어 mannitol, dextran, 유기산과 이산화탄소 등이 생성될 경우 환원당은 오히려 감소하기도 한다고 보고되어 있다(26).

\section{총 폴리페놀 화합물의 함량}

섬애약숙 추출물이 첨가된 식혜의 당화 과정 중 총 폴리 페놀 화합물의 함량은 Table 7에서와 같이 쑥 추출물의 혼합 비율이 높을수록, 당화시간이 경과할수록 증가하여 당화 5 시간에는 $10.59-29.80 \mathrm{mg} / \mathrm{mL}$ 의 범위였다. 섬애약쑥 추출물을 $5 \%$ 첨가하였을 때는 당화시간의 경과와 더불어 꾸준히 총 폴리페놀 화합물의 함량이 증가하였으나 10-20\% 첨가군의 경우 당화 4시간째에 가장 큰 폭으로 증가 하였다. 즉, 섬애약쑥 추출물 $5 \%$ 첨가군의 경우 당화 시간 별로 이전 시간 대비 총 폴리페놀 화합물의 함량을 산출한
결과 최고 증가율은 약 $12 \%$ 인 반면 $10-20 \%$ 첨가군은 당화 4시간째에 평균 약 $29 \%$ 증가하였다.

식혜 제조시 오디 농축액을 $0.5 \%$ 첨가하였을 때는 무첨 가군과 차이가 없으나 $1 \%$ 이상 첨가하였을 때는 무첨가군 에 비해 폴리페놀 화합물의 함량이 약 2 배 정도 더 증가하 며, 오디 농축액의 첨가량이 많을수록 폴리페놀 화합물의 함량은 더 증가하였다는 보고(29)가 있다. Park(25)은 커피 박 열수추출물을 첨가한 식혜의 총 폴리페놀 화합물의 함량 은 첨가비율이 높을수록 더 높았는데 이는 커피박 추출액에 함유된 총 폴리페놀 화합물이 식혜성분으로 이행되었기 때문이라고 보고한 바 있다. 이는 본 연구와 동일한 경향이 었으며, 본 연구결과에서 총 폴리페놀 화합물도 원재료인 엿기름과 섬애약쑥 추출물에서 기인한 것으로 판단된다.

쑥의 열수 추출물 중 페놀화합물로는 chlorogenic acid의 함량이 가장 높아 약 $40 \%$ 를 차지한다는 보고(30)가 있으며, 개똥쑥 물 추출물에서 chlorogenic acid, salicylic acid, sinapic acid, vanilic acid, protocatechuic acid가 $200 \mathrm{mg} / \mathrm{kg}$ 이상 함유되어 있고, 이들 이외에 5 종의 페놀화합물이 더 확인되었다고 보고되어 있다(31). 쑥 뿐만 아니라 식물체 내에 함유되어 있는 페놀화합물은 다양한 구조와 분자량을 가지는 2 차 대사산물로 체내 생체막에 존재하는 지질이 활성산소에 의한 유리기와의 연쇄반응하여 산화를 유발하 고, 노화를 일으키는 원인으로 작용하는 과정에서 유리기 를 효과적으로 제거함으로써 생체 내 항산화활성을 나타내 는 기능성 성분으로 알려져 있다(1).

\section{$\mathrm{DPPH}$ 라디칼 소거활성}

섬애약쑥 추출물을 첨가하여 완성한 쑥 식혜의 항산화 활성을 DPPH 라디칼 소거활성으로 평가한 결과는 Table 8 과 같다. 섬애약쑥 추출물의 첨가 비율이 높아질수록 $\mathrm{DPPH}$ 라디칼 소거활성도 증가되어 당화 전 대조군의 활성 은 $4.81 \%$ 에 불과하였으나 섬애약쑥 추출물 $20 \%$ 첨가군의 경우 $64.62 \%$ 로 유의적으로 높은 함량이었다. 이는 홍국쌀 을 $20 \%$ 첨가하여 제조한 식혜의 경우 대조군에 비해 DPPH

Table 8. Changes in DPPH radical scavenging activity during saccharification of Sikhye added with Seomaeyaksuk extract

\begin{tabular}{ccccccc}
\hline \multirow{2}{*}{$\begin{array}{c}\text { Mixture ration of } \\
\text { mugwort extract (\%) }\end{array}$} & \multicolumn{5}{c}{ Saccharification time (h) } \\
\cline { 2 - 7 } & 0 & 1 & 2 & 3 & 4 & 5 \\
\hline 0 & $4.81 \pm 0.08^{1 \mathrm{la} 2) \mathrm{A} 3)}$ & $7.11 \pm 0.04^{\mathrm{bA}}$ & $23.98 \pm 0.16^{\mathrm{fA}}$ & $18.82 \pm 0.04^{\mathrm{eA}}$ & $17.99 \pm 0.00^{\mathrm{dA}}$ & $11.16 \pm 0.07^{\mathrm{cA}}$ \\
5 & $20.28 \pm 0.04^{\mathrm{aB}}$ & $24.80 \pm 0.00^{\mathrm{bB}}$ & $25.94 \pm 0.17^{\mathrm{bB}}$ & $26.50 \pm 0.02^{\mathrm{cB}}$ & $63.47 \pm 0.01^{\mathrm{BB}}$ & $39.49 \pm 0.03^{\mathrm{dB}}$ \\
10 & $29.63 \pm 0.01^{\mathrm{aC}}$ & $31.01 \pm 0.06^{\mathrm{bC}}$ & $41.49 \pm 0.02^{\mathrm{CC}}$ & $57.25 \pm 0.09^{\mathrm{dC}}$ & $68.32 \pm 0.12^{\mathrm{fC}}$ & $66.47 \pm 0.05^{\mathrm{eC}}$ \\
15 & $54.07 \pm 0.01^{\mathrm{aD}}$ & $61.97 \pm 0.16^{\mathrm{bD}}$ & $72.11 \pm 0.04^{\mathrm{cD}}$ & $84.57 \pm 0.07^{\mathrm{eD}}$ & $90.25 \pm 0.00^{\mathrm{fD}}$ & $81.96 \pm 0.07^{\mathrm{dD}}$ \\
20 & $64.62 \pm 0.05^{\mathrm{aE}}$ & $84.70 \pm 0.02^{\mathrm{bE}}$ & $86.14 \pm 0.02^{\mathrm{dE}}$ & $85.99 \pm 0.00^{\mathrm{cE}}$ & $92.65 \pm 0.01^{\mathrm{EE}}$ & $84.70 \pm 0.00^{\mathrm{bE}}$ \\
\hline
\end{tabular}

\footnotetext{
${ }^{1)}$ Each value is a mean \pm SD of 5 samples.

2)a-f Means with different letters in the same row are significantly different at $p<0.05$ by Duncan's multiple range test.
}

${ }^{3) A-E}$ Means with different letters in the same column are significantly different at $p<0.05$ by Duncan's multiple range test. 
라디칼 소거활성이 약 2.2 배 더 높았으며, 홍국쌀의 첨가 비율이 높을수록 활성이 더 높았다는 $\mathrm{Na}$ 등(32)의 보고와도 일치하는 결과였다.

당화시간이 경과함에 따라 라디칼 소거활성도 증가하는 경향을 보이다가 다시 감소하였는데, 대조군의 경우 당화 2 시간째에 $23.98 \%$ 로 가장 높은 활성을 보인 후에 활성이 감소하여 최종 5 시간 당화 후에 활성은 $11.16 \%$ 에 불과하였 다. 섬애약쑥 추출물 첨가군들의 경우 당화 4시간에 최고의 활성을 보인 이후 활성이 감소하였는데, 섬애약쑥 추출물 $5 \%$ 첨가군은 최고 $63.47 \%$ 로 활성이 높았다가 $39.49 \%$ 로 당화 5 시간째의 활성은 당화 4 시간째의 활성에 비해 약 $57 \%$ 수준으로 감소하였다. 섬애약쑥 추출물의 첨가 비율이 $10 \%$ 이상인 경우에는 동일한 경향이지만 활성의 감소 폭이 더 적어 당화 4시간 시료 대비 당화 5시간 시료의 활성은 약 91-97\% 수준을 유지하여 활성은 $66.47-84.70 \%$ 였다.

본 연구의 결과에서 섬애약쑥 식혜의 DPPH 라디칼 소거 활성은 쑥의 활성에 기인하는 것으로 판단되는데, 전국의 산과 들에서 8 종 이상 100 계통의 쑥을 채집하여 항산화 활성을 평가한 결과 모든 쑥이 BHT $200 \mathrm{ppm}$ 과 유사한 우수한 항산화활성을 나타내었으며 이러한 활성은 쑥 중에 함유된 페놀화합물과 높은 정의 상관성을 가지기 때문이라 고 보고되어 있다(33).

\section{관능검사}

섬애약쑥 추출물의 첨가 비율을 달리하여 완성한 식혜의 관능평가 결과는 Table 9 와 같다. 섬애약쑥 추출물의 첨가 비율이 높아질수록 색에 대한 기호도는 낮아져서 $20 \%$ 첨가 군의 경우 3.25 으로 가장 낮았고, 평소에 익숙한 식혜의 색인 대조군에서 6.46 으로 가장 높았다. 쑥 향의 경우도 색과 동일한 경향이었으며 섬애약쑥 추출물 $10 \%$ 와 $15 \%$ 첨가군 간에는 통계적인 유의차가 없었으나 $20 \%$ 첨가군은 유의적으로 기호도가 낮았다. 이는 쑥 추출물 $5 \%$ 첨가군은 은은한 쑥 향을 제공함으로써 대조군과 유의차 없이 높은 선호도를 보인데 반해 쑥 추출물이 $20 \%$ 첨가됨으로 인해 색이 너무 진하고, 쑥 향이 강하여 기호도를 오히려 저하시 켰기 때문으로 생각된다. 감미는 섬애약쑥 추출물 $5 \%$ 첨가
군의 경우 대조군과 통계적인 차이가 없었으나 쑥 추출물이 $10 \%$ 이상 첨가됨으로써 유의적으로 기호도가 낮아졌다. 이는 쑥 추출물의 첨가량이 증가함에 따라 쑥 추출물 자체 의 쓴맛이 영향을 미쳤기 때문으로 판단된다. 밥알의 퍼짐 성은 섬애약숙 추출물의 첨가량이 증가할수록 기호도가 낮아지는 경향이었으나 통계적인 유의차는 없었다. 전체적 인 기호도 평가 결과 섬애약쑥 추출물 $5 \%$ 첨가군의 경우 대조군과 차이가 없었고, 섬애약쑥 추출물 $10 \%$ 와 $15 \%$ 첨 가군은 서로 간에 유의적인 차이가 없었다.

\section{요 약}

전통 음료인 식혜의 기능성 강화를 위한 연구의 일환으 로 섬애약쑥 추출물을 0. 5, 10, 15 및 $20 \%$ 첨가하여 식혜를 제조하고, 5 시간 동안 당화 시키면서 1 시간 간격으로 품질 특성을 분석하였다. 섬애약쑥 추출물을 첨가한 식혜의 탁 도는 당화 2시간에 최고치를 보인 후 점차 감소하는 경향을 나타내었으며, 당화 5시간에는 섬애약쑥 추출물 $5-15 \%$ 첨 가군 간에는 유의적인 차이가 없었고, $20 \%$ 첨가군은 유의 적으로 높았다. 쑥 식혜의 명도값은 당화 완료 후 모든 실험 군에서 유의적인 차이가 없었다. 적색도와 황색도는 당화 시간이 경과하고 섬애약쑥 추출물의 첨가량이 많을수록 더 높은 경향이었다. 당화 전 $\mathrm{pH}$ 는 섬애악쑥 추출물의 첨가 비율에 따른 유의차는 없었고, 당화 완료 후 5.68-5.73의 범위로 증가하였다. 가용성 고형분 및 환원당의 함량은 당 화 시간의 경과와 섬애약쑥 추출물의 첨가 비율이 많을수록 높아지는 경향이었다. 총 폴리페놀 화합물의 함량과 DPPH 라디칼 소거활성도 당화 시간과 섬애약숙 추출물의 첨가와 정의 상관관계를 나타내며 높아졌다. 관능평가 결과에서는 섬애약쑥 추출물 $5 \%$ 첨가군은 대조군과 차이가 없었으나 $20 \%$ 첨가군의 경우 강한 색과 쑥 향으로 인해 기호도가 낮았고 전체적인 기호도도 유의적으로 낮았다. 이상의 결 과를 종합하여 볼 때 섬애약쑥 추출물을 첨가한 식혜의 경우 쑥 추출액의 첨가량이 높을수록 항산화활성이나 이화 학적 특성은 향상되었지만 관능평가에서는 오히려 기호도

Table 9. Sensory evaluation of Sikhye added with Seomaeyaksuk extract

\begin{tabular}{cccccc}
\hline $\begin{array}{c}\text { Mixture ration of } \\
\text { mugwort extract (\%) }\end{array}$ & Color & Mugwort flavor & Sweet taste & Spreading of rice & All acceptability \\
\hline 0 & $6.46 \pm 0.31^{1 \mathrm{D} 2)}$ & $6.01 \pm 0.41^{\mathrm{C}}$ & $5.63 \pm 0.54^{\mathrm{C}}$ & $5.63 \pm 0.54^{\mathrm{A}}$ & $5.56 \pm 0.27^{\mathrm{C}}$ \\
5 & $5.42 \pm 0.32^{\mathrm{C}}$ & $5.85 \pm 0.22^{\mathrm{C}}$ & $5.27 \pm 0.47^{\mathrm{BC}}$ & $5.47 \pm 0.41^{\mathrm{A}}$ & $5.49 \pm 0.33^{\mathrm{C}}$ \\
10 & $4.84 \pm 0.29^{\mathrm{B}}$ & $4.89 \pm 0.32^{\mathrm{B}}$ & $4.69 \pm 0.24^{\mathrm{AB}}$ & $5.39 \pm 0.31^{\mathrm{A}}$ & $4.98 \pm 0.22^{\mathrm{B}}$ \\
15 & $4.65 \pm 0.58^{\mathrm{B}}$ & $4.76 \pm 0.21^{\mathrm{B}}$ & $4.57 \pm 0.17^{\mathrm{A}}$ & $5.25 \pm 0.22^{\mathrm{A}}$ & $4.86 \pm 0.12^{\mathrm{B}}$ \\
20 & $3.25 \pm 0.20^{\mathrm{A}}$ & $3.14 \pm 0.42^{\mathrm{A}}$ & $4.06 \pm 0.21^{\mathrm{A}}$ & $4.95 \pm 0.18^{\mathrm{A}}$ & $4.20 \pm 0.31^{\mathrm{A}}$ \\
\hline
\end{tabular}

${ }^{1)}$ Each value is a mean \pm SD of 25 person's test results.

2)A-D Means with different letters in the same column are significantly different at $p<0.05$ by Duncan's multiple range test. 
가 낮아지므로 적정 첨가비율은 $15 \%$ 이내가 적합한 것으로 판단된다.

\section{감사의 글}

본 논문은 산업통상자원부의 지역주력산업 육성 기술개 발 사업(과제번호: R0004407)의 지원에 의해 수행된 연구 결과의 일부입니다.

\section{References}

1. Choi MH, Kang JR, Sim HJ, Kang MJ, Seo WT, Bae WY, Shin JH (2015) Physicochemical characteristics and antioxidant activity of Seomaeyaksuk depending on harvest times and processing methods. Korean J Food Preserv, 22, 399-407

2. Lee SD, Park HH, Kim DW, Bang BH (2000) Bioactive constituents and utilities of Artemisia sp. as Medicinal herb and foodstuff. Korean J Food Nutr, 13, 490-505

3. Hwang CR, Seo WT, Bae WY, Kang MJ, Shin JH (2014) Physicochemical characteristics and biological activities of Artemisia Argyi H. J Life Sci, 24, 377-385

4. Hwang CR, Seo WT, Kang MJ, Shin JH (2013) Antioxidant activity of the Seomaeyaksuk tea extracts prepared with different drying and extract conditions Korean J Food Preserv, 20, 546-553

5. Kim KH, Kim SJ, Yoon MH, Byun MW, Jang SA, Yook HS (2011) Change of anti-oxidative activity and quality characteristics of Maejakgwa with mugwort powder during the storage period. J Korean Soc Food Sci Nutr, $40,335-342$

6. Choi IK, Lee JH (2013) Quality characteristics of Yanggaeng incorporated with mugwort powder. J Korean Soc Food Sci Nutr, 42, 313-317

7. Yang S, Kim MY, Chun SS (2008) Quality characteristics of Yukwa prepared with mugwort powder using different puffing process. Korean J Food Cookery Sci, 24, 340-348

8. Moon EW, Park HJ, Park JS, Lee MK, Na HS (2015) Quality properties of rice cake containing Artemisia annua L. powder. Korean J Food Preserv, 22, 811-816

9. Park SI (2006) Application of green tea powder for Sikhe preparation. Korean J Food Nutr, 19, 227-233

10. Kim GS (2013) Utilization of Korean traditional drinks and quality characteristics of Sikhe added with Cnidium officinale Makino water extrects. MS Thesis, Catholic
University of Daegu, Korea, p 20-41

11. Kim JS (2012) Quality characteristics of Sikhye with mulberry fruits. Korean J Culi Res, 18, 206-215

12. An YH, Lee IS, Kim HS (2011) Quality characteristics of Sikhye with varied levels of sweet pumpkin during storage. Korean J Food Cookery Sci, 27, 803-814

13. Lee JH (2011) Quality of Sikhye incorporated with hot water extract of Omija (Schisandra chinensis Baillon) fruit. Food Eng Prog, 15, 80-84

14. Hur SS (2007) Change in the composition of ginseng Sikhye during the saccharification process. Korean J Food Preserv, 14, 650-654

15. Yang JW, Jung SK, Song KM, Kim YH, Lee NH, Hong SP, Lee KH, Kim YE (2015) Quality characteristics of Sikhye made with berries. J East Asian Soc Dietary Life 25, 1007-1017

16. Jeong KY, Lee EJ, Kim ML (2012) Storage properties and sensory characteristics of Sikhye added Ulmus pumila L. extract. Korean J Food Preserv, 19, 12-18

17. Kim HH, Park GS, Jeon JR (2007) Quality characteristics and storage properties of Sikhye prepared with extracts from Hovenia dulcis THUNB. Korean J Food Cookery Sci, 23, 848-857

18. Min SH (2009) Quality characteristics of Sikhye prepared with Astragalus membranaceus water extracts. J East Asian Soc Dietary Life, 19, 216-223

19. Cho KM, Joo OS (2010) Manufacture of Sikhye (a traditional Korean baverage) using corn silk extracts. Korean J Food Preserv, 17, 644-651

20. Miller GL (1959) Use of dinitrosalicylic acid reagent for determination of reducing sugar. Anal Chem, 31, 426-428

21. Gutfinger T (1981) Polyphenols in olive oils. J Am Oil Chem Soc, 58, 966-968

22. Blois MS (1958) Antioxidant determination by the use of a stable free radical. Nature, 181, 1199-1200

23. Lee MW (2011) pH, turbidity, color, brix, reducing sugar, total sugar, ketose, amino acid, protein and organoleptic characteristics of puffed rice powder added Sikhye during saccharification. MS Thesis, Seoul National University, Korea

24. Kim GS, Park GS (2012) Quality characteristics of Sikhye prepared with Cnidium officinale Makino water extracts. J East Asian Soc Dietary Life, 22, 868-878

25. Park LY (2014) Quality characteristics and antioxidant activity of Sikhye prepared using hot water extracts of roasted coffee ground residue. Korean J Food Sci 
Technol, 46, 470-476

26. Kang MJ, Ju JC, Shin JH (2013) Quality characteristics of Sikhye prepared with farlic powder and steamed garlic powder. J Agric Life Sci, 47, 247-255

27. Jang HG, Jung DH (1996) Food Analyse. Hyungseul Publishing Co, Seoul, Korea, p 217

28. Ryu BM, Kim JS, Kim MJ, Lee YS, Moon GS (2008) Comparison of the quality characteristics of Sikhye made with $\mathrm{N}_{2}$-circulated low temperature dry malt and commercial malts. Korean J Food Sci Technol, 40, 311-315

29. Yang JW, Jung SK, Song KM, Kim YH, Lee NH, Hong SP, Lee KH, Kim YE (2016) Quality characteristics of Sikhye added with mulberry (Morus alba L.) fruit concentrate. J East Asian Soc Dietary Life, 26, 44-54
30. Kang YH, Park YK, Oh SR, Moon KD (1995) Studies on the physiological functionality pine needle and mugwort extracts. Korean J Food Sci Technol, 27, 978-984

31. Ryu JH, Lee SJ, Kim MJ, Shin JH, Kang SK, Cho KM, Sung NJ (2011) Antioxidant and anticancer activities of Artemisia annua L. and determination of functional compounds. J Korean Soc Food Sci Nutr, 40, 509-516

32. Na SJ, Choi SH, Lee SH, Ahn JS, Kim JS (2013) Quality characteristics of Sikhye made with Monascus Anka rice. Korean J Culinary Res, 19, 46-56

33. Choi YM, Chung BH, Lee JS, Cho YG (2006) The antioxidant activities of Artemisia spp. collections. Korean J Crop Sci, 51, 209-214 